\title{
COLONIAL RESEARCH IN THE BRITISH COMMONWEALTH
}

$\mathrm{T}$ WHE reports for 1954-55 of the Colonial Research Council and of the eight specialist advisory bodies and the Director of the Anti-Locust Research Centre are contained in a substantial publication of more than three hundred pages entitled "Colonial Research 1954-55"*. In addition, there are some notes on research matters not covered by the reports of the specialist advisory bodies, and appended is a list of schemes approved for research grants under the Colonial Development and Welfare Acts, April 1, 1954-March 31, 1955. At the end of each of the reports are lists of publications; and, with the membership of the various Councils or Committees and their terms of reference, the publication as a whole gives an impressive picture not merely of the magnitude and range of the effort devoted to research in Colonial problems by Great Britain but equally of the extent to which that effort is interlocked with the research organization generally in Britain whether in the universities or in government establishments. No document better calculated to refute the idea that there is any inherent reproach in the word 'Colonial' could easily be conceived.

The report of the Colonial Research Council points out that with the coming into force of the Colonial Development and Welfare Act, 1955, the provision for 1955-60 calls for an average annual research expenditure of $£ 1,600,000$ as against $£ 1,173,381$ during the year ended March 31, 1955, and an average of $£ 1,240,000$ over the past four years. Expenditure in the several fields of research is at different stages of development, necessitating continuous review of the financial situation, and the Colonial Research Council held the first of such roviows in April 1955 to consider the allocation of the available funds among the various fields of research. The fifty-two now schemes and forty-eight supplementary schemes made during the year, involving grants totalling $£ 533,548$, brought the net commitment chargeable against Colonial Development and Welfare Funds since 194.0 to $£ 12.5$ million. Of the gross allocation of $£ 13.5$ million, $32 \cdot 5$ per cent has been for agricultural, animal health and forestry schemies, 15 per cent for medical research, $11 \cdot 8$ per cent for fisheries research, $9 \cdot 7$ per cent for tsetse and trypanosomiasis research, 9 per cent for social science and economic research, 7.9 per cent for insecticides research, 5 per cent for research sponsored by the Colonial Products Research Council, $3 \cdot 6$ per cent for anti-locust research and $5 \cdot 5$ per cent for miscellaneous schemes, including building and road research. About 39 per cent has been for schemes to benefit the East African Territories, 18 per cent for the West African group, 10 per cent for the South-East Asian Territories and Hong Kong, 8.8 per cent for the West Indian Colonies, British Guiana and British Honduras and 5.6 per cent for the Central African Territories.

- Colonial Office. Colonial Research, 1954-55. (Reports of the Colonial Research Council; Colonial Products Council; Colonial Social Seience Research Council; Colonial Medical Research Committee; Committee for Colonial Agricultural, Animal Health and Forestry Research; Colonial Insecticides Committee; Colonial Economic Research Committee; Tsetse Fly and Trypanosomiasis Research Committee; Colonial Fisheries Advisory Committee ; Director, Anti-Locust Research, and Research Matters not covered by the above Reports of the Specialist Advisory Bodies.) Pp. 316.
(Cmd. 9626.) (London: H.M.S.O., 1955.) 98. net.
Much the largest scheme approved during the year was $£ 104,024$ for the establishment and maintenance for an initial two years of the East African Scientific and Industrial Research Organization, but $£ 50,000$ was provided for the establishment and maintenance of the Colonial Road Research Section at the Road Research Laboratory, Harmondsworth, a supplementary $£ 42,500$ for the East African Medical Survey, and a supplementary $£ 37,750$ for the maintenance of the Anti-Locust Research Centre and its extra-mural activities. $£ 31,483$ was provided for the purchase of buildings at Kabete for the East African Veterinary Research Organization, $£ 22,329$ for the establishment of the Agricultural Research Station at Aden, $£ 17,780$ for silvicultural research in Nyasaland, and supplementary $£ 16,683$ for the Desert Locust Survey, $£ 16,365$ for maintenance of the Ebini Livestock Experimental Station, British Guiana, and $£ 14,390$ for maintenance of the Colonial Insecticides Research Unit, Porton.

The second annual report of the Colonial Products Council and Colonial Products Laboratory records that the Laboratory dealt with 829 inquiries during the year, and completed eighty-four investigations. Those of major interest included an examination of oil of Leptospermum citratum, which indicated a citral content of 40 per cent, and one of the limonene obtained as a by-product in the concentration of sweet orange oil, which showed the limonene to be of good commercial quality. Examination of the oleo-resin collected in an experimental tapping trial from Pinus caribaea Morelet in British Honduras was completed and also a second trial distillation on a larger scale. The effects of insect attack on groundnuts were further studied, and five species of illipe nuts that were examined for the agricultural authorities of Sarawak contained 64-66 per cent saturated acids, 33-35 per cent oleic acid and about 1 per cent of linoleic and more unsaturated acids.

Detailed studies were made of the composition of Barbados sugar-cane wax; and a further sample of sisal wax from Kenya gave wax polishes comparable with those obtained by using carnauba wax, but emulsion polishes hardened on standing. A study of the development of acidity in maize under insect attack has been started, and, in further work on the chromatographic resolution of the active principles of pyrethrum flowers, reversed-phase chromatography using silicone-impregnated kieselguhr columns gave a good separation of the pyrethrin I and pyrethrin II fractions. Further progress has been made in building up the reference collection of photo-micrographs of fibres from botanically authenticated plants, and a satisfactory fibre was obtained from experimental yarn produced in a bulk spinning trial on a sample of Nigerian anaphe silk, probably derived from Epanaphe moloneyi.

At the Colonial Microbiological Research Institute, Trinidad, a start has been made in following the microbiology of 'microfermatories', and the distribution of free sugars and glycosides in the cacao bean has been studied. Further work on the development of the antifungal antibiotic, comirin, now lies mostly outside the scope of the Institute, but the nature of the antibiotic effect against fungi and 
yeast has been more closely investigated in an attempt to elucidate the point of attack of comirin on the fungus. The preliminary difficulties encountered at the newly established jute estate near New Amsterdam in British Guiana now seem to have been overcome, and retting dry ribbon no longer seems to be a problem, but the original difficulties point to the necessity for 'seasoning' tanks and using a 'starter'. The Sugar Technological 1 Laboratory, Trinidad, has completed work in connexion with the modernization of the experimental sugar factory, and studies on the variation of cane-juice constituents with plant growth conditions have shown that in the greenhouse a refractory juice can be produced to order by simply controlling the water supply to the cane. Use of sodium fluoride in clarification has been examined critically, and a study undertaken of the thermal conductivity of sugar cane, while a detailed study is being made of the soft fatty fraction obtained as a by-product of wax manufacture.

Investigations into the production of fibreboard from secondary Colonial timbers continued at the Forest Products Research Laboratory, Princes Risborough, where experimental work on the processing conditions for hardboard from four Malayan timbers has been completed. At the University of Birmingham work continued on the synthesis of cellulose by the organisms Acetobacter acetigenum and Acetobacter xylinium, and on the characteristics of dextransucrase from Leuconostoc arabinosaceus, and the mechanism of the reaction between sugars and amino-acids was being investigated using model sugar-amino-acid systems; the anti-acetylcholine activity of several series of compounds, including antihistamine agents, has been determined, and it was observed that introduction of several halogen atoms in the molecules of three classes of antihistamines modified their anti-acetylcholine activity. At the Royal Technical College, Glasgow, the constitution of the triterpene alcohol, taraxerol, has been determined, and investigations into the nature and properties of the undesirable highly coloured constituents of mangrove tanning extracts continued at the University of Leeds. At the University of Nottingham the Colonial hardwood, rengas, has been shown to contain two pigments, the more abundant being probably 4: $3^{\prime}: 4^{\prime}$-trihydroxybenzylidene-6-methoxycoumarone, with very small amounts of an isomer, and the quantitative aspect of the production of oligosaccharides from glucose and the purification of Floridean starch have been studied at the University College of North Wales, Bangor.

The eleventh annual report of the Colonial Social Science Research Council, to which are appended reports from the East African Institute of Social Research, the West African Institute of Social and Economic Research, the Institute of Social and Economic Research, University College of the West Indies, the Rhodes-Livingstone Institute, the Educa. tional Research Institute for Fiji and Western Pacific Territories, and the Social Research Unit, University of Malaya, expresses the opinion that, while funds available for research by individual scholars will be severely limited, the new allocation of $£ 525,000$ should suffice for a reasonable level of activity by the regional Institutes of Socirl and Economic Research, provided they can attract funds from other sources. Much time was devoted by the Council during the year to the question of making regional institutes ready for transfer as university institutes to the parent universities and university colleges at the end of their present Colonial Development and Welfare period, but the success of these plans depends largely on matters outside the Council's control. The Council for Technical Co-operation in Africa South of the Sahara has set up an Inter-African Committee for Social Sciences, and the first inter-African conference under the auspices of the Committee was arranged at Bukavu during August-September 1955.

The research section of the Department of Social Welfare in Singapore completed a socio-economic survey of family living conditions in Singapore City and also a survey of listening habits and tastes of Chinese households, while in Malaya the Department of Aborigines undertook some ethnological research, mainly to establish the geographical distribution and to collate material on the political and social organization of aboriginal tribes. Twenty-six volumes of the Ethnographic Survey of Africa had been published by the end of the year, and two further volumes were in the press. The first volume of the North Bantu Borderland Linguistic Survey was also ready for the press. A bibliographical survey of available material on labour productivity in British African Colonies is being made, and the preparation of a Ga-Adangme dictionary was started. A study of Iban agriculture, the last of the anthropological studies in Sarawak, is in the press. At the East African Institute of Social Research, work in Buganda was mainly in connexion with the study of change in patterns of authority and social stratification in Buganda and the North Nyanza district of Kenya. The West African Institute of Social and Economic Research expects in the near future, over and above the research programme for its permanent staff, to assist a five-year programme for a cultural history of Benin and a survey of the groundnut-and cottonproducing areas of Northern Nigeria. Research in progress at the Rhodes-Livingstone Institute covers both urban and rural studies, including a social survey of Livingstone, a study of family economics and nutrition in the copper belt of Northern Rhodesia and field work among the Lungu. Studies by the three Fellows comprising the Social Research Unit, University of Malaya, have included an analysis of land usages and transfers at Parit Sulong, with particular reference to the alleged encroachment of Chinese, and an examination of inter-racial attitudes, their bases and rationale, the relation of Chinese farmers at Sungei Derhaka, in Province Wellesley, to the Malays on whose land they have settled and among whom they work, and the social conditions of the inhabitants of a street in the 'Chinatown' area of Singapore.

Six small schemes, applicable to the tropics, two of which were for home-based work at the Universities of Liverpool and London, were added to the twentyone established research schemes under the supervision of the Colonial Medical Research Committee at the beginning of the year. The Committee's tenth annual report records five new appointments to overseas research units, two of which were to newly created posts, and states that the Colonial medical research studentships are increasingly filling their purpose. Tribute is also paid to the value of the work of the Sub-Committee on the Sickle-Cell 'Irait. in fostering research in this field, while the Helminthiasis Sub-Committee has recommended that a group of young zoologists should be given basic training under recognized specialists in the varied 
aspects of malacology, in particular the systematics of the snail, at appropriate laboratories at Glasgow, Liverpool, Reading, London and perhaps in Europe or the United States, and also afforded opportunities to study the infestation overseas. The East African Standing Advisory Committee for Medical Research stresses the need for statistical and demographic studies and for co-operation among agricultural, veterinary and medical workers concerned with nutrition. The East African Council for Medical Research held its first meeting in January 1955, and the West African Council for Medical Research met for the first time in March 1955 at Lagos.

Studies on loiasis in the Cameroons and Nigeria have included the continued study of the population of flies and its infection-rate at Kumba and Sapele; the biting-cycle of $C$. silacea at all levels of the forest up to and above the canopy, using an improved technique for scaling the giant trees in the tropical rain forest, and trial of the use of 'Hetrazan' in controlling the transmission of loiasis. It seems likely that use of 'Banocide' for this purpose may be of practical value in developed areas where the popula. tion can be adequately covered and monkeys are not a potential reservoir. Infection of captive monkeys (Mandrillus leucophaeus) has now been achieved. In East Africa the Filariasis Research Unit has now been merged with the Medical Survey. In Malaya, blood surveys made by the Filariasis Research Unit at Kuantan, along the Pahang River, revealed a high incidence $(60$ per cent microfilaria-rate in those aged 4-5 years) in young children, and the results suggest that a very high rate of transmission occurs indoors and that most infections are thus acquired. Experiments to find a practicable treatment by 'Hetrazan' continued on carriers of $W$. malayi, and trappings of mosquitoes with Mangoon (stable) traps confirmed that Mansoniodes longipalpis (longipalpis plus bonneae) is the major vector and that it will feed on many animals and is equally attracted to man or goat.

Investigations on guinea-worm at University College, Ibadan, indicate that Thermocyclops nigerianus Kiefer is the most widespread intermediate host in south-west Nigeria and is highly adapted to pond water. Laboratory and field studies on the trans. mission of vesical schistosomiasis continued in the Gambia and, with its further expansion during the year by a group of World Health Organization workers, the designation of the East African Malaria Unit has been changed to the East African Institute of Malaria and Vector-Borne Diseases, to accord with its increasing scope. Continued examination of 'Dieldrin' as a mosquito larvicide has shown it to be some ten times as lethal as DDT, and the granulated form is a valuable new preparation. The Malaria Control Pilot Project in Western Sokoto, Northern Nigeria, found a surprisingly rapid loss of potency of residual 'Dieldrin', DDT and BHC on the mud walls of human dwellings. In solid form 'Dieldrin' and 'Lindane' were the most effective toxicants against the larvæ of Aedes aegypti and Culex fatigans; in aqueous suspensions the order of efficiency was 'Dieldrin', 'Lindane', DDT. In Kenya, investigations were initiated on the metabolism of Plasmodium knowlesi; using the fluctuation in quantity of the adenosine phosphates as an indicator of the energy resources in the parasite--erythrocyte complex, it was found that the parasite draws upon the energy resources of the erythrocyte during its multiplication in the blood stream, and that the adenosine tri- phosphate and diphosphate contents vary inversely with the percentage of parasitized cells.

A detailed entomological survey to determine to what degree West African strains of Aedes aegypti are domestic species and therefore accessible to larvicidal control measures, and whether this species is the sole or even the most.important local vector, has been commenced in and around Ilobi, a typical rain-forest belt village fifty miles from Lagos, while from the results of surveys of yellow-fever antibody in man and monkey made during the past ten years certain epidemiological patterns in south, southwest, eastern and northern Nigeria emerge.

In a study on the relation of the virus to its insect host, the East African Virus Research Institute at Entebbe has concentrated on the genetical and breeding aspect, to elucidate why only some mosquitoes are infectible; other studies at Entebbe concern the relation of virus to host tissues and the behaviour of Rift Valley fever in the mouse, while in collaboration with the Laboratoire Médicale de Stanleyville, Belgiann Congo, a survey was made of yellow-fever immunity among forest pigmies. Tests of the Malayan strain of Aedes aegypti have shown that under laboratory conditions it is a most effective vector for the transmission of yellow-fever virus by bite. The Trinidad Regional Virus Laboratory, Port of Spain, has given full attention to yellow fever, following the isolation of yellow-fever virus from a patient from a forestal region of Trinidad; immunity surveys have also revealed that dengue is widespread throughout the island and that ilheus is widespread in the lowland high-rainfall-forest-cocoa area. In Malaya sera from six rural communities exposed to different predominant biting mosquitoes were being examined for antibodies to yellow fever and Japanese encephalitis, and a comprehensive clinical and laboratory study of acute febrile illnesses in and around Kuala Lumpur was undertaken to define their etiology and determine the part that arthropodborne viruses might play in their causation. Study of Japanese encephalitis in Malaya was extended to a search for the natural mosquito vector, and at the Lister Institute of Preventive Medicine, Elstree, the identification of blood-meals of insects continued.

In Uganda the work on the body composition of malnourished African subjects before and after feeding with high-calorific diets of high protein content continued, and the water and protein contents of muscle obtained at autopsy and operation were investigated; studies of the hæmoglobin and serum protein of subjects living in the high (non-malarious) districts and in the lower (malarious) districts of Kigezi led to the tentative conclusion that the high values for gamma-globulin are in part due to malarial infection. Data on the potassium and sodium concentrates in the plasma of infants suffering from kwashiorkor show that plasma potassium values in children who do not suffer from severe diarrhœa are within control limits. At the Hot Climate Physiological Research Unit, Nigeria, a statistically designed investigation was made of certain variables in the standard Harvard pack test. A long series of trials began on the effect of air movement on performance, and also preliminary work on the distribution of body fluid and the composition of the body. An active programme of leprosy work at Singapore included a chemotherapeutic trial of isonicotinic hydrazide, and a study was made of the interrelationship of the Mantoux and Lepromin reactions in an attempt to evaluate the use of B.C.G. vaccine as a prophylactic 
in leprosy, which indicated that leprosy attacks essentially the Mantoux-negative individuals and that infection with tuberculosis resulted in some resistance to leprosy. A new mass-treatment campaign has been started in Keneba against Microfilaria bancrofti infection using 'Hetrazan' in conjunction with an anti-histamine drug. The search for new antibiotic-producing organisms, particularly streptomyces, from Malayan soil continues, and further mosquito infectivity experiments have confirmed that, in patients carrying gametocytes of a proguanilresistant strain of $P$. falciparum, anopheline mos. quitoes can be infected from a person taking $0.4 \mathrm{gm}$. proguanil daily. Further observations in the Kitui kala-azar area indicate that an anthropophilic species, provisionally designated Phlebotomus (Sergentomyia) sp. nov. 2, is the most likely vector of the epidemic, and experiments in Fiji indicate that the most effective dosage of 'Hetrazan' for control of filariasis is one $50-\mathrm{mgm}$. tablet taken on one day per month for twelve months.

( $T$ o be continued)

\section{FOURTH NATIONAL CLAY CONFERENCE IN THE UNITED STATES}

$\mathrm{T}$

HE Fourth National Clay Conference of the National Clay Minerals Committee, United States, was held in the Department of Mineral Industries of the Pennsylvania State University, University Park, Pennsylvania, and consisted of seven sessions during the three days October 11-13. Approximately fiftyfour papers were presented. Participants came from all regions of the United States, as well as seven from overseas: Dr. G. F. Walker (Australia), Dr. W. Dekeyser (Belgium), Prof. U. Hofmann (Germany), Dr. J. L. White and Dr. D. M. C. MacEwan (Great Britain), Prof. T. Sudo (Japan), Prof. J. M. Albareda (Spain). Dr. Hénin (France) was prevented by illness from attending. E. W. Radoslovich (Australia), J. Kulbicki (France), J. Zussman (Great Britain) and H. Heystek (South Africa), who were on extended visits to the Pennsylvania State University, were also present.

With such a wealth of papers, it would be difficult to give a detailed report. The present account concentrates on certain topics which seemed to me to be of importance, and is bound to be coloured by personal interests. It may, however, not be entirely a matter of personal prejudice that the study of interstratified, or mixed-layer clay minerals, appeared to emerge as one of the important growing-points of this branch of science. Their existence was reported many years ago by Alexander and others ${ }^{1}$, and, since then, gradually increasing numbers of studies of such minerals have been appearing. At the Pennsylvania meeting, a whole session was devoted to this topic. The use of Geiger-counter recording apparatus for $\mathrm{X}$-ray diffraction allows very extensive surveys to be made in a relatively short time. C. E. Weaver reported on the examination of three thousand sedimentary rocks, his conclusion being that interstratified clays are among the commonest mineral types present in the clay fraction. Systems identified are randomly interstratified illite-montmorillonite, chlorite-vermiculite, illite-chlorite-montmorillonite, chlorite-kaolinite, and regularly interstratified chlor. ite-vermiculite. A vermiculite-illite system, weathering to a 'chloritic' system (alumina in interlayer positions), was reported from New Zealand soils by T. Tamura. Schmehl and Jackson directed attention to the presence in soil clays of amorphous 'relicts', not giving distinct diffraction maxima, even on heating. T. Sudo reported certain Japanese acid clays which are randomly mixed kaolinite-montmorillonite; some of these minerals show almost no basal reflexions, a phenomenon which has not been satisfactorily explained. Vanadium silicates resembling clay minerals were described by J. C. Hathaway, who reported that they show mixed-layer expanding structures, mica-montmorillonite and chlorite-montmorillonite.

The name 'corrensite' has been proposed' for (apparently) a regular 1: 1 montmorillonite-chlorite, and two occurrences of similar material were described at this meeting by J. W. Early and I. H. Milne. Vermiculite-chlorite systems from soil and shales were described by H. Heystek. D. M. C. MacEwan reported a Fourier-transform investigation of a micamontmorillonite interstratified system in a Silurian clay from Worcestershire, the system being strikingly similar to the 'Kinnekulle II' clay from Sweden'. E. W. Tooker found mixed-layer illite-montmorillonites as stages in the series biotite-illite-montmorillonite (in an extensive paper on altered wall-rocks in the Pre-Cambrian of Colorado).

R. Roy, with his collaborators, has continued his important studies at the Pennsylvania State University on clay synthesis and equilibria, and he reported (with D. M. Roy) on hydrogen-deuterium exchange and the assignment of infra-red frequencies in clays (a caution against a too lighthearted assignment of absorption maxima to certain atomic groupings), and also on thermal transformations in dickite-namely, the formation of kaolinite by hydrothermal treatment of 'metadickite' and 'meta-metahalloysite', these substances being, of course, the analogues of 'metakaolin'. With F. A. Mumpton he has investigated the relation of ionic substitution to hydrothermal stability of montmorillonoids. Saponites are the most stable; the addition of polarizable ions $\left(\mathrm{Zn}^{2+}, \mathrm{Ni}^{2+}\right)$ decreases the stability, as does the substitution of $\mathrm{Ga}^{3+}$ for $\mathrm{Al}^{3+}$ in beidellite. The interlayer ions also affect stability. Mumpton and Roy have further succeeded in synthesizing both regularly and randomly interstratified minerals.

G. W. Brindley and his collaborators have been continuing detailed structural work on clays. At the meeting, Newnham and Brindley reported on the structure of dickite, a two-dimensional Fourier investigation, which shows the octahedral layer of this mineral to have distortions of the same general type as in gibbsite (the first study of this sort on a dioctahedral mineral of the clay group); and on allevardite, confirming in general the results of Caillère et al.4. Brindley and Radoslovich have commenced a study of the hydrothermal alteration of single crystals of felspars. In Dr. Hénin's absence, Prof. Brindley also read his paper on low-temperature synthesis of clay minerals.

Other structural studies were reported by J. Zussman and G. F. Walker. Zussman proposes to divide the serpentine minerals into ortho- and clinochrysotile, antigorite, and a third variety with orthogonal packing. (Whittaker, reporting on these minerals in November to the Mineralogical Society in London, proposed the name 'lizardite' for this 